Журнал«Герстективита інновації наукиљ

(Серія «Гедагогіка», Серія«Гтихологія», Серія«Медицина»

№(6) 2022

УДК 37.036:378.2

https://doi.org/10.52058/2786-4952-2022-1(6)-86-96

Варгата Оксана Валеріївна кандидат педагогічних наук, доцент кафедри психології та педагогіки, Хмельницький національний університет, вул. Інститутська, 11, м. Хмельницький, 29000, тел.: (067) 379-01-19, https://orcid.org/0000-0002-1805-4643

Кулешова Олена Віталіївна кандидат психологічних наук, доцент кафедри психології та педагогіки, Хмельницький національний університет, вул. Інститутська, 11, м. Хмельницький, 29000, тел.: (067) 933-49-80, https://orcid.org/0000-0001-5428-2670

Міхесва Людмила Василівна кандидат педагогічних наук, доцент кафедри психології та педагогіки, Хмельницький національний університет, вул. Інститутська, 11, м. Хмельницький, 29000, тел.: (097) 544-76-94, https://orcid.org/0000-0003-0369-1129.

\title{
ТЕХНОЛОГІЯ САSЕ-STUDY У ПРОЦЕСІ ВИКЛАДАННЯ ПСИХОЛОГО-ПЕДАГОГІЧНИХ ДИСЦИПЛІН
}

Анотація. У статті здійснений теоретичний аналіз технології case-study та ефективність ii використання у процесі викладання психолого-педагогічних дисциплін. Розкрито поняття: «технологія», «педагогічна технологія», «технологія case-study», «викладання», «технологія case-study у процесі викладання психолого-педагогічних дисциплін».

Окреслено психолого-дидактичні принципи технології case-study y процесі викладання психолого-педагогічних дисциплін. Визначено структуру та зміст технології case-study у процесі викладання психолого-педагогічних дисциплін. Проаналізовано основні ознаки та ідеї використання case-study під час викладання психолого-педагогічних дисциплін. Охарактеризовано основні завдання технології case-study у процесі викладання психолого-педагогічних дисциплін, а саме: оволодіння аналітичними навичками; формування практичних навичок; розвиток творчих навичок; розвиток комунікативних навичок; розвиток соціальних навичок; розвиток критичного та аналітичного мислення. Обгрунтовано психолого-педагогічні умови щодо реалізації технології case-study у процесі викладання психолого-педагогічних дисциплін.

У статті здійснено емпіричне вивчення навчальної мотивації за методикою «Мотивація навчання у вищому навчальному закладі». Завданням емпіричного дослідження було дослідити, яка мотивація переважає у майбутніх психологів. Для визначення результатів запропоновано три шкали «Здобування знань», «Оволодіння професією» та «Отримання диплома» та 
ключ за допомогою якого можливо дослідити, яка мотивація переважає у досліджуваного. Згідно проведеного опитування визначено, що у більшості опитаних студентів-психологів сформована внутрішня мотивація, яка забезпечує розуміння важливості навчального процесу, зацікавленість в отримані нових знань та відпрацюванні необхідних вмінь, саме для таких студентів-психологів технологія case-study буде ефективною та сприятиме розвитку необхідних навичок.

Ключові слова: технологія, педагогічна технологія, технологія casestudy, викладання, технологія case-study у процесі викладання психологопедагогічних дисциплін.

Varhata Oksana Valeriivna $\mathrm{PhD}$ in Pedagogical Sciences, docent Department of Psychology and Pedagogy, Khmelnytsky National University, Institutskaya St., 11, Khmelnytsky, 29000, tel.: (067) 379-01-19, https://orcid.org/0000-0002-1805-4643

Kuleshova Olena Vitaliivna $\mathrm{PhD}$ in Psychological Sciences, docent Department of Psychology and Pedagogy, Khmelnytsky National University, Institutskaya St., 11, Khmelnytsky, 29000, tel.: (067) 933-49-80, https://orcid.org/0000-0001-5428-2670.

Mikheieva Liudmyla Vasylivna $\mathrm{PhD}$ in Pedagogical Sciences, docent Department of Psychology and Pedagogy, Khmelnytsky National University, Institutskaya St., 11, Khmelnytsky, 29000, tel.: (097) 544-76-94, https://orcid.org/0000-0003-0369-1129.

\section{CASE-STUDY TECHNOLOGY IN THE PROCESS OF TEACHING PSYCHOLOGICAL AND PEDAGOGICAL DISCIPLINES}

Abstract. The article provides a theoretical analysis of case-study technology and the effectiveness of its use in the teaching of psychological and pedagogical disciplines. The main concepts are: «technology», «pedagogical technology», «casestudy technology», «teaching», «case-study technology in the process of teaching psychological and pedagogical disciplines».

Psychological and didactic principles of case-study technology in the process of teaching psychological and pedagogical disciplines were outlined. The structure and content of case-study technology in the process of teaching psychological and pedagogical disciplines were determined. The main features and ideas of case-study use in teaching psychological and pedagogical disciplines were analyzed. The main tasks of case-study technology in the process of teaching psychological and pedagogical disciplines were described such as: mastering analytical skills; formation of practical skills; development of creative skills; development of communication skills; development of social skills; development of critical and analytical thinking. Psychological and pedagogical conditions for the 
implementation of case-study technology in the process of teaching psychological and pedagogical disciplines were substantiated.

There was an empirical study of learning motivation according to the method "Motivation of learning in higher education" in the article. The task of the empirical study was to investigate what main motivation which prevails in future psychologists. To determine the results there were proposed three scales «Gain the knowledge», «Mastering the profession» and «Obtaining a diploma» and a key with which it is possible to investigate which motivation prevails in the subject. According to the survey it is determined that most of the surveyed students of psychology have an inner motivation that provides understanding of the importance of the educational process, interest in gaining new knowledge and skills, for such students of psychology case-study technology will be effective and promote the necessary skills.

Key words: technology, pedagogical technology, case-study technology, teaching, case-study technology in the process of teaching psychological and pedagogical disciplines.

Постановка проблеми. Викладання психолого-педагогічних дисциплін потребує пошуку та використання нових технологій навчання, які мають охоплювати перевірку теоретично набутих знань та практичне напрацювання необхідних професійних умінь та навичок, які забезпечуватимуть ефективність роботи. Досить поширеним $є$ те, що попри здатності фахівця до аналізу ситуації, розумінні сутності проблеми, знанні можливих шляхів вирішення, він не $є$ спроможним до того, щоб діяти та використовувати все це у своїй професійній діяльності. Що потребує того, що під час навчання використовувались технології, які забезпечуватимуть практичність набутого досвіду. Вивчення психолого-педагогічних дисциплін потребує наявність високорозвинутих пізнавальних властивостей особистості, прагнення до саморозвитку та творчої активності. Тому за доцільне нами розглянуто методкейсів, як сучасна технологія викладання, що забезпечує розвиток гнучкості, критичності та систематичності мислення та навчає практично застосовувати свої теоретичні знання для вирішення нагальних питань.

Аналіз останніх досліджень та публікацій. Вивчення технології case-study та можливості iї застосування у процесі викладання психологопедагогічних дисциплін розглядають у своїх дослідженнях: В. Кротенко [4], Г. Рідкодубська [8], І. Леонтьєва [5], І. Романов [9], Л. Козак [3], О. Андрієць [1], О. Долгоруков [3], С. Ковальова [11], Т. Білецька [2], Т. Пащенко [7], Ю. Сурмін [10] та ін.

Мета статті - здійснити теоретичний аналіз технології case-study та ефективність іiі використання під час викладання психолого-педагогічних дисциплін.

Виклад основного матеріалу. Процес викладання психологопедагогічних дисциплін вимагає поєднання у своїй діяльності теоретичних 
знань та практичних умінь, основним завданням є не лише засвоєння знань, розвиток вміння ефективно застосовувати ці знання та набуті навички, використовуючи наявні можливості в різноманітних умовах педагогічної взаємодіі.

Викладання розглядається як діяльність викладача, що організована за спеціальних умов з ціллю підготовки та забезпечення успішності освітнього процесу, який має бути спрямованим на оволодіння актуальною інформацією та потенційними можливостями іiі ефективного використання у подальшій діяльності.

У наукових джерелах розглядають різноманітні цілі вивчення психологопедагогічних дисциплін, серед яких [11]:

- формування психологічної грамотності, шляхом розширення загальних знань $з$ психології;

- краще розуміння власної життєдіяльності, вивчення власних особливостей характеру та темпераменту, особистісних характеристик для можливості подальшого розвитку сильних сторін та корекції слабких;

- розвиток навичок психологічного мислення, що розширює кругозір та коло можливостей, яке має значно ширші межі;

- теоретичне вивчення, опрацювання та засвоєння технік психологічної допомоги іншим та можливим способам самодопомоги у різноманітних кризових ситуаціях.

У наш час модернізації системи освіти є потреба у процесі викладання дисциплін з використанням новітніх інноваційних методів та форм роботи або вмілого поєднання 3 різноманітними технологіями, для формування високорозвинутих, компетентних та кваліфікованих фахівців.

Поняття педагогічна технологія $є$ досить широким та означає певну систему функціонування всіх компонентів навчально-виховного процесу, що має відповідати зазначеним вимогам: результативності, відтворюваності, концептуальності, системності, керованості [6].

Для ефективного викладання психолого-педагогічних дисциплін вважаємо за доцільне впровадження технології case-study, що 3 англійської мови має прямий переклад й означає вивчення випадку та розглядається як аналіз ситуацій, який має відбуватись інтенсивно 3 урахуванням індивідуального підходу та акцентувані відносно розвитку [1].

У своїх дослідженнях Ю. Сурмін зазначає два аспекти, що поєднуються у даному методі. У першому випадку це емпіричні дослідження, що розвиває дослідницькі навички та розвиває пошукові здібності для поєднання різноманітних інформаційних джерел. Другим аспектом є навчання шляхом обговорення ситуацій та розгляду ऑï 3 декількох сторін, яка навчає використовувати наявні вміння та зазначені умови для продуктивності діяльності.

Автор визначає те, що даний метод розвиває важливі характеристики особистості, які забезпечуватиме ефективність професійної діяльності та 
кваліфікаційну підготовку: спроможність до теоретичного аналізу та необхідної діагностики проблемних питань; уміння до чіткого та точного формулювання й висловлення своєї думки та здатності відстоювати прийняту позицію; розвиває культуру спілкування, яка полягає у можливості до дискусії, адекватному сприйнятті та об'єктивному оцінюванні різної інформації; формує впевненість у своїх силах, шляхом формування адекватної оцінки можливостей [10].

У своїх дослідженнях Т. Білецька зазначає, що застосування технології case-study в процесі викладання психолого-педагогічних дисциплін має базуватися на єдності таких дидактичних принципів: індивідуальний підхід; забезпечення наочності; максимальній свободі у процесі навчанні; формуванні навичок самостійності, самоорганізованості, вмінні працювати з інформацією; зосередженні уваги на основних положеннях, а не на значному обсязі теоретичного матеріалу; розвиток позитивних якостей [2].

Структура case-study складається 3 конкретно запропонованої ситуації (проблемного випадку, історії з життя), описаного контексту (хронологія, історія, умови, фактори, можливості) та коментар від автора у вигляді запитання чи завдання для роботи [9].

У своїх дослідженнях Л. Козак розглядає «кейс» з методичної точки зору, як цілеспрямовано заздалегідь підготовлений матеріал для навчального процесу, що описує певну ситуацію чи випадок 3 реального життя, що створюватиме атмосферу нагальної проблеми для студента в можливій практичній діяльності та буле мотивувати до пошуку ефективних рішень [3].

В літературних джерелах зазначають, що сутність case-study розкривається в самостійній пізнавальній діяльності, яка розвивається за допомогою вирішення проблемних питань, що створені у штучному середовищі, яке дозволяє спробувати використовувати свої теоретичні знання для набуття практичного досвіду. При використанні даної технології у процесі викладання психолого-педагогічних дисциплін важливо підібрати та створювати ситуативні завдання та умови з урахуванням даної спеціальності. основним завданням для викладача є активізація здобувачів до пошуку істини різноманітними способами та методами, нестандартними шляхами та поєднанням різних підходів [3; 5].

У своїх дослідженнях О. Долгоруков виділяє певні ознаки case-study: наявність заздалегідь підготовленої моделі проблемної ситуації, що буде розглядатись; пошук рішень має колективну спрямованість; обов'язковим $є$ наявність декількох альтернативних рішень; єдина мета під час вирішення проблемних завдань; створення певної системи, що дозволятиме колективно оцінювати діяльність; емоційна напруга студентів під час пошуку рішень має бути керована [3].

Згідно наукових досліджень кейси поділяються на [9]:

1. Науково-дослідні, для яких є важливим здійснення дослідницької діяльності; 
2. $\quad$ Практичні, для яких є доречним відображення реальних ситуацій;

3. Навчальні, що орієнтовані на організацію та покращення ефективності освітнього процесу.

У нашому дослідженні, ми більш детально розглянемо навчальний кейс, що виступає, як інструмент реалізації технології case-study в процесі викладання психолого-педагогічних дисциплін. Активне застосування якого, на наш погляд, сприятиме підвищенню професійної майстерності викладача та підвищуватиме ефективність навчання здобувачів, розширить їх можливості у отриманні практичного досвіду, що для них є досить актуальним.

Використання case-study під час викладання психолого-педагогічних дисциплін має враховувати такі його основні ідеї [7]:

1. Завдання мають бути призначені для отримання знань та побудовані таким чином, що існує декілька альтернативних шляхів вирішення запропонованих випадків, що можуть відрізнятись ступенем істинності, спонукає до дискусії, відстоювання власної точки зору, презентації власних думок, що значно розширює кругозір, через наявні можливості відхилення від стандартних способів мислення та сприйняття.

2. Увага акцентується не на засвоєння готових знань, а на його практичне вироблення, у процесі спільної творчої діяльності, креативності, гнучкості, критичності у взаємодії студента та викладача. 3 цього одразу спостерігається відмінність 3 традиційними методами навчально-виховного процесу в якому переважає авторитарний стиль, для case-study властивим $\epsilon$ демократична взаємодія у процесі отримання та засвоєння знань, коли існують рівні права між студентом і викладачем у розробці та під час обговорення запропонованих випадків.

3. У результаті використання методу відбувається комплекс засвоєння теоретичних знань та практичних навичок, що необхідні для ефективного виконання професійної діяльності.

4. Реалізація відбувається за такою технологією: для роботи розробляється певна модель конкретного проблемного випадку, що трапляється у реальності, а вирішення якого відображатиме комплекс знань та вмінь, на розвиток яких спрямоване навчання та які необхідно розвинути для подальшої ефективної діяльності; викладач виступає у ролі ведучого, який керує процесом вирішення ситуації ставить питання, фіксує активність та запропоновані відповіді, провокує та підтримує дискусію, виступає посередником.

5. Використання даного методу розвиває та може розширювати систему цінностей, професійних й особистісних позицій, набутих установок, сформованого стереотипного мислення та шаблонів у діяльності.

6. Ефективно організований кейс сприяє прояву творчої активності, емоційності, прояву чесної конкуренції та створює атмосферу довіри та підтримки.

У науковій літературі виділяють такі особливості технології case-study [10]: 
Журнал«Герспективитаінновації науки»

(Серія«Гедагогіка», Серія«ГЕихологія», Серія«Медицина»

№1(6) 2022

- якісні дослідження неоднозначних випадків, що базується на різних джерелах знань;

- застосування творчості та креативності, але з наявним алгоритмом;

- орієнтація на колективну пізнавальну діяльність, яка розглядається як передумова синергетичного ефекту;

- забезпечення ситуації занурення у випадок, який сприяє поєднанню логічного та образного, інсайтного пізнання, що розширює можливості мислення.

Завданнями технологія case-study у процесі викладання психологопедагогічних дисциплін $є$ [3; 4]:

- оволодіння аналітичними навичками, які є корисними при дослідженні, обробці й аналізі різноманітних даних, структуровані, класифіковані, що відбувається шляхом розділення інформації на фрагменти для детальнішого вивчення, кращого розуміння та встановлення причинно-наслідкових зв'язків;

- формування практичних навичок, шляхом формування практичних умінь, яке відбувається при використання набутих теоретичних знань для вирішення запропонованих кейсів, для перевірки власних переконань та упереджень, відбувається набуття власного досвіду та формується спроможність вирішувати нагальні проблеми та приймати рішення «тут i тепер»;

- розвиток творчих навичок, що відбувається у результаті пошуку різноманітних шляхів вирішення ситуацій та $є$ важливим для генерування нових альтернативних рішень;

- розвиток комунікативних навичок, для того, щоб грамотно вести дискусію, чітко та ясно презентувати зібрані матеріали, вміти переконувати та відстоювати власну позицію, впевнено обгрунтовувати свою точку зору;

- розвиток соціальних навичок, які виробляються при аналізі та обговорені ситуаційних випадків та груповій взаємодії;

- самоаналіз та осмислення власних думок та позиції інших, розвиває спроможність до адекватного прийняття конструктивної критики, за допомогою розвинутого критичного та аналітичного мислення;

Для ефективності використання технології case-study під час викладання психолого-педагогічних дисциплін важливо дотримуватись таких принципів [3]:

- відповідність цілям навчання;

- максимальна наближеність до реальності;

- завдань має передбачати декілька можливих шляхів вирішення;

- актуальність запропонованих кризових ситуацій;

- рівень складності ситуацій може відрізнятись.

Основною метою використання даного методу у процесі викладання психолого-педагогічних дисциплін є активне залучення здобувачів до аналізу, 
вирішення та обговорення запропонованих проблемних ситуацій та повинно виконуватись за таких психолого-педагогічних умов [8]:

1. Високий рівень складності запропонованих проблемних випадків, що стимулюють розвиток пізнавальної сфери студентів.

2. Ситуації та відповідні до них запитання маю бути логічно побудовані щодо проблеми, проте мати можливість до творчого та нестандартного пошуку вирішення, яких має бути декілька можливих.

3. У процесі педагогічної взаємодії між учасниками має бути забезпечена атмосфера психологічного комфорту, довіри та підтримки.

4. Під час виконання завдань обов'язковим $€$ відведення часу на осмислення та переосмислення усіх запропонованих способів та методів вирішення поставлених завдань.

5. Для викладачів $є$ необхідним попередня організація підготовки до впровадження даної технології у навчальному процесі для викладання психологічних дисциплін.

Досліджуючи технологію case-study у літературних джерелах, ми вважаємо за доцільне зосередити увагу на перевагах ії використання у процесі викладання психолого-педагогічних дисциплін [7]:

- набуття практичного особистісного досвіду;

- формування сталого інтересу до навчальної дисципліни;

- активне засвоєння необхідних професійних навичок;

- формування впевненості у власних можливостях;

- розширення кругозору та розвиток критичності мислення.

Проте дана технологія має певні недоліки, такі як: мало вивчений 3 психолого-педагогічної точки зору; вимагає затрати часу як у підготовці, так і під час використання; потребує від педагога попередньої підготовки та обізнаності для ефективного використання [7;10].

За результатами теоретичного вивчення ми дослідили, що основною проблемою для впровадження case-study у навчальний процес $є$ недостатня обізнаність можливостями використання даної технології, відсутність розроблених кейсів із психологічних дисциплін i недостатня навчальна мотивація.

3 метою вивчення навчальної мотивації нами було проведено дослідження за методикою «Мотивація навчання у вищому навчальному закладі» ( Т. Ільїна) у якому було опитано 75 респондентів. Завданням було дослідити, яка мотивація переважає у студентів. У даній методиці було запропоновано 50 тверджень, відповідно з якими потрібно погодитись «+» чи ні «-». Для визначення результатів запропоновано три шкали «Здобування знань», «Оволодіння професією» та «Отримання диплома» та ключ за допомогою якого можливо дослідити, яка мотивація переважає у досліджуваного. Результати за методикою відображені на рисунку 1. 


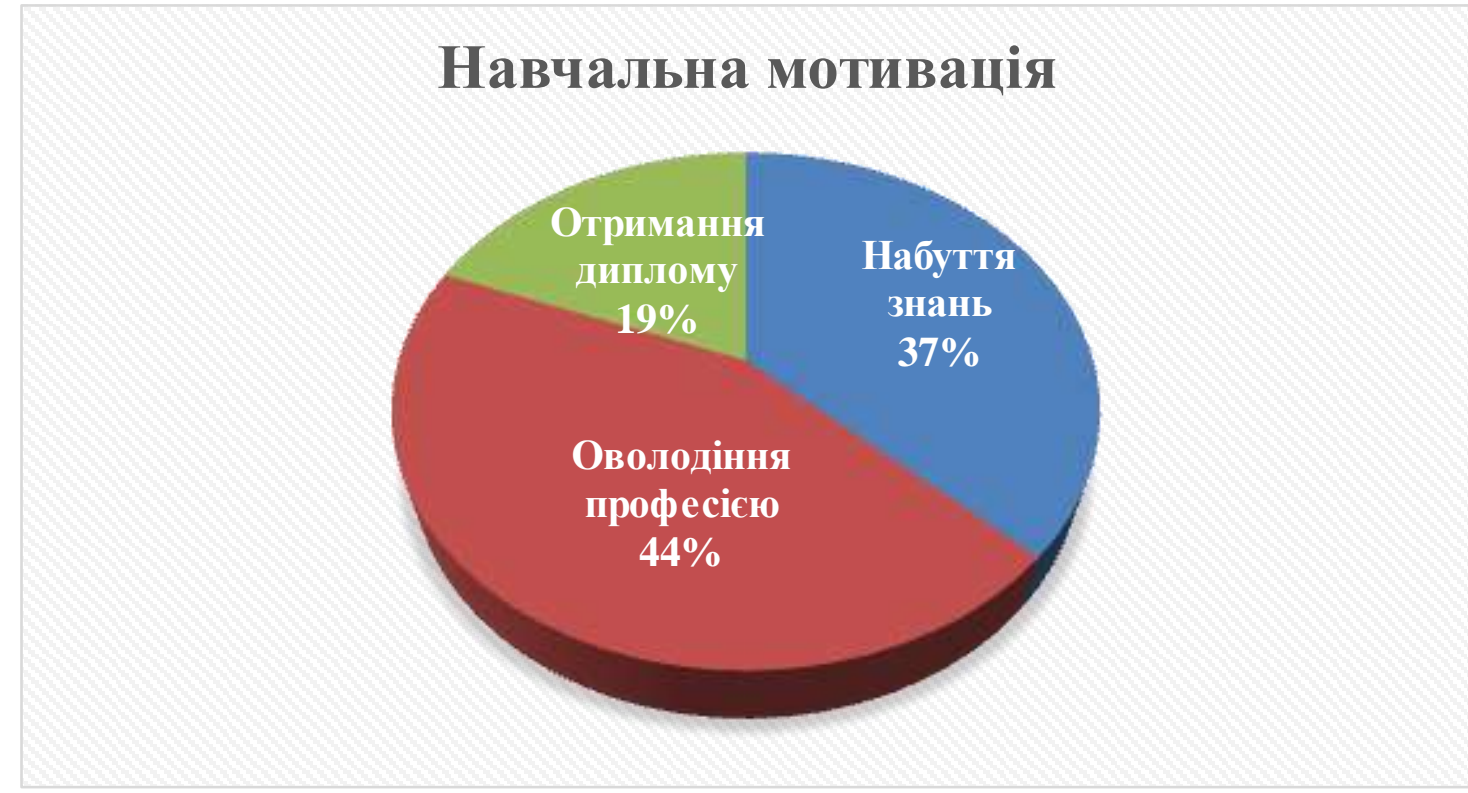

Pис.1. Результати за методикою «Мотиваиія навчання» ( Т. Ільїна)

За результатами дослідження нами виявлено, що серед опитаних студентів переважає мотивація за шкалою «Оволодіння професією» - 44\%, що означає прагнення до набуття професійно важливих навичок, які забезпечуватимуть ефективність у роботі; за шкалою «Набуття знань» - 37\%, що означає допитливість та спрямованість на вивчення нового, розширення кола своїх знань, прагнення до розвитку; за шкалою «Отримання диплому» $19 \%$, що означає формальність навчання у закладі та незацікавленість у освітньому процесі.

Згідно проведеного опитування визначено, що у більшості опитаних студентів сформована внутрішня мотивація, а саме $81 \%$ (сумарний результат за шкалами «Оволодіння професією» та «Набуття знань»), яка забезпечує розуміння важливості навчального процесу, зацікавленість в отримані нових знань та відпрацюванні необхідних вмінь, саме для них технологія case-study буде ефективною та сприятиме розвитку необхідних навичок. Для решти опитуваних у яких мотивація спрямована на отримання диплому, дана технологія не матиме такого впливу, проте, ми вважаємо, за корисне іiі використовувати і для даної категорії. Так як, іноді теоретична частина не може зацікавити у процесі навчання, а практичне відпрацювання може мати протилежний ефект.

На наш погляд, варто поінформувати учасників освітнього процесу про технологію case-study, яка стимулює індивідуальну активність студентів, формує позитивну мотивацію до навчання, забезпечує високу ефективність освітнього процесу, формує професійно необхідні компетенції, та одночасно створює можливість для викладачів самовдосконалюватись, по-іншому сприймати оточуючий світ та постійно розвиватись.

Висновки. Здійснивши теоретичний аналіз означеної проблеми у науковій літературі, визначено ефективність технології case-study у процесі 
викладання психолого-педагогічних дисциплін, що забезпечує єдність теоретичних знань та напрацювання практичного, що відбувається у процесі демократичної взаємодії між учасниками, у результаті чого відбувається колективний обмін досвідом, вирішення проблемних завдань шляхом всебічного та різностороннього аналізу, що дозволяє знаходити усі можливі альтернативи вирішення та забезпечує отримання необхідного професійного досвіду. Використання кейсів у процесі викладання психолого-педагогічних дисциплін допоможе студентам усвідомити наявність труднощів у практичній діяльності, проте наддасть можливість попередньо відпрацювати набуті знання та вміння, що забезпечить певний досвід та сприятиме розвитку впевненості у власних силах. Перспективи подальших досліджень, вбачаємо у розробці психологічного супроводу щодо впровадження кейс-технології у викладанні психолого-педагогічних дисциплін у вищому навчальному закладі.

\section{Лimepamypa:}

1. Андрієць О. М. Використання кейс-методу у формуванні та розвитку дискурсного мовлення старшокласників // Педагогіка формування творчої особистості у вищій i загальноосвітній школах. 2019. с. 56-58.

2. Білецька Т. В. Використання «кейс-методу» у викладанні соціально-гуманітарних дисциплін [Електронний ресурс]. Режим доступу до pecypcy: metodychnyj-biuletenperedo...iky-ta-sotsialno-ekonomichnykh-dystsyplin-2021-rik.

3. Козак Л. В. Кейс-метод у підготовці майбутніх викладачів до інноваційної професійної діяльності // Освітологічний дискурс. 2015. с. 153-162.

4. Кротенко В. І. Використання кейс-методу у професійній підготовці психологів (спеціальних, клінічних) // Педагогіка формування творчої особистості у вищій і загальноосвітній школах. 2021. с. 96-100.

5. Леонтьєва I. В. Педагогічний кейс як засіб розвитку критичного мислення майбутніх викладачів // Збірник наукових праць. 2019. с. 29-38.

6. Ліхачов В. К. Кейс-технології як продуктивний засіб формування компетентнісних професійних навичок на етапі медичної післядипломної освіти [Електронний ресурс] / [B. К. Ліхачов та ін.]. Режим доступу до ресурсу: file:///C:/Users/\%D0\%90\%D0\%BD\%D1\%8F/Downloads/\%D0\%BA\%D0\%BE\%D0\%BC\%D0\%B F\%D0\%B5\%D1\%82\%D0\%B5\%D0\%BD\%D1\%86\%D1\%96\%D1\%97\%20\%D0\%BA\%D0\%B5\% D0\%B9\%D1\%81\%D1\%83.pdf.

7. Пащенко Т. М. Методологічні аспекти кейс-методу при викладанні спеціальних дисциплін будівельного профілю [Електронний ресурс]. Режим доступу до ресурсу: file://C:/Users/\%D0\%90\%D0\%BD\%D1\%8F/Downloads/\%D0\%BA\%D0\%B5\%D0\%B9\%D1\%81.pdf.

8. Рідкодубська Г. А. Кейс-метод у процесі підготовки до професійної мобільності майбутніх працівників соціальної сфери // Педагогічні науки. 2017. с. 246-250.

9. Романов I. Р. Метод кейсів: перспективи використання у навчанні майбутніх правознавців англійської мови // «Молодий вчений». 2017. с. 529-534.

10. Сурмін Ю. П. Кейс-метод: становлення та розвиток в Україні. [Електронний ресурс]. Режим доступу до ресурсу: file:///C:/Users/\%D0\%90\%D0\%BD\%D1\%8F/ Downloads/04.pdf.

11. Тарасова Т. Б. Методика навчання психології у вищій школі : навчальний посібник. Суми : Вид-во СумДПУ імені А. С. Макаренка, 2019. 361с. 


\section{References:}

1. Andriec', O. M. (2019). Vikoristannja kejs-metodu u formuvanni ta rozvitku diskursnogo movlennja starshoklasnikiv [The use of the case method in the formation and development of discourse speech of high school students]. Pedagogika formuvannja tvorchoï osobistosti u vishhij $i$ zagal'noosvitnij shkolah - Pedagogy of creative personality formation in higher and secondary schools, 56-58 [in Ukrainian].

2. Bilec'ka, T. V. Vikoristannja «kejs-metodu» u vikladanni social'no-gumanitarnih disciplin [The use of the "case method" in the teaching of social sciences and humanities]. Retrived from metodychnyj-biuleten-peredo...iky-ta-sotsialno-ekonomichnykh-dystsyplin-2021-rik [in Ukrainian].

3. Kozak, L. V. (2015). Kejs-metod u pidgotovci majbutnih vikladachiv do innovacijnoï profesijnoï dijal'nosti [Case-method in the preparation of future teachers for innovative professional activities]. Osvitologichnij diskurs - Educational discourse, 153-162 [in Ukrainian].

4. Krotenko, V. I. (2021). Vikoristannja kejs-metodu u profesijnij pidgotovci psihologiv (special'nih, klinichnih) [The use of the case method in the training of psychologists (special, clinical)]. Pedagogika formuvannja tvorchoï osobistosti u vishhij i zagal'noosvitnij shkolah - Pedagogy of creative personality formation in higher and secondary schools, 96-100 [in Ukrainian].

5. Leont'єva, I. V. (2019). Pedagogichnij kejs jak zasib rozvitku kritichnogo mislennja majbutnih vikladachiv [Pedagogical case as a means of developing critical thinking of future teachers]. Zbirnik naukovih prac' - Collection of scientific papers, 29-38 [in Ukrainian].

6. Lihachov, V. K. Kejs-tehnologiï jak produktivnij zasib formuvannja kompetentnisnih profesijnih navichok na etapi medichnoï pisljadiplomnoï osviti [Case-technologies as a productive means of forming competent professional skills at the stage of medical postgraduate education]. Retrived from file:///C:/Users/\%D0\%90\%D0\%BD\%D1\%8F/Downloads/\% D0\%BA\% D0\% BE\% D0\%BC\%D0\%BF\%D0\%B5\%D1\%82\%D0\%B5\%D0\%BD\%D1\%86\%D1\%96\%D1\%97\%20\%D0 \%BA\%D0\%B5\%D0\%B9\%D1\%81\%D1\%83.pdf [in Ukrainian].

7. Pashhenko, T. M. Metodologichni aspekti kejs-metodu pri vikladanni special'nih disciplin budivel'nogo profilju [Methodological aspects of the case method in teaching special disciplines of construction profile]. Rezhim dostupu do resursu: file://C:/Users/\%D0\%90\% D0\%BD\%D1\%8F/Downloads/\%D0\%BA\%D0\%B5\%D0\%B9\%D1\%81.pdf [in Ukrainian].

8. Ridkodubs'ka, G. A. (2017). Kejs-metod u procesi pidgotovki do profesijnoï mobil'nosti majbutnih pracivnikiv social'noï sferi [Case-method in the process of preparation for professional mobility of future workers in the social sphere]. Pedagogichni nauki - Pedagogical Sciences, 246-250 [in Ukrainian].

9. Romanov, I. R. (2017). Metod kejsiv: perspektivi vikoristannja u navchanni majbutnih pravoznavciv anglijs'koï movi [The case method: prospects for the use of future English lawyers in teaching]. "Molodij vchenij» - "Young Scientist", 529-534 [in Ukrainian].

10. Surmin, Ju. P. Kejs-metod: stanovlennja ta rozvitok v Ukraïni. [Case method: formation and development in Ukraine]. Retrived from file://C:/Users/\%D0\%90\%D0\%BD\%D1\%8F/ Downloads/04.pdf [in Ukrainian].

11. Tarasova, T. B. (2019). Metodika navchannja psihologii u vishhij shkoli [Methods of teaching psychology in high school]. Sumi : Vid-vo SumDPU imeni A. S. Makarenka [in Ukrainian]. 